\title{
EASTER ISLAND FOUNDATION NEWS
}

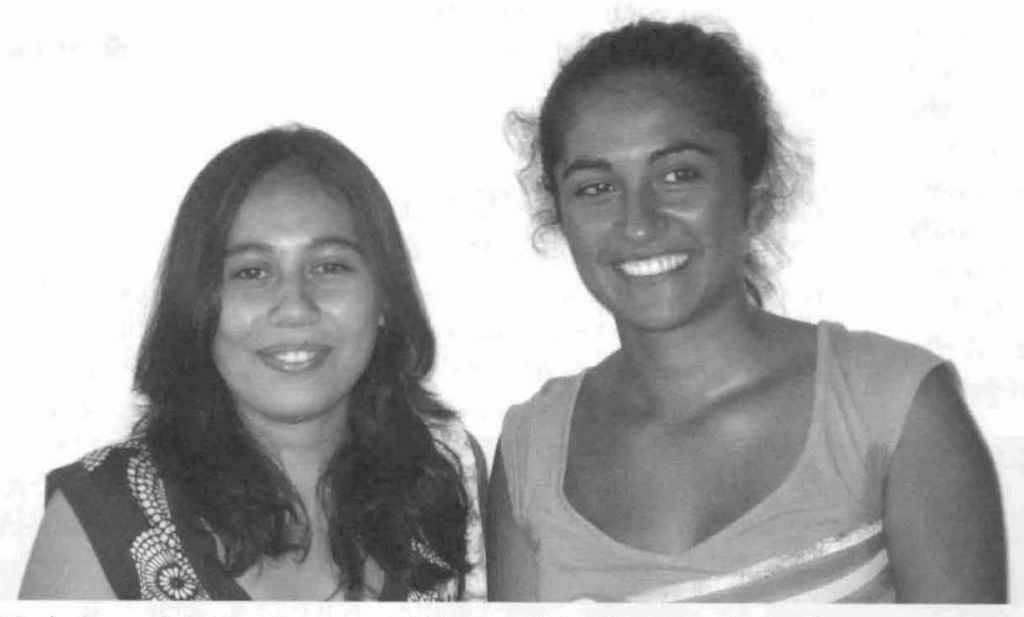

Maria Eugenia Huke Fuentes and Rutirangi Tuki Paoa smile for the camera as they received notice of their awards. The island's Governor, Melania Carolina Hotu Hey, is a member of the Foundation's Scholarship Committee member, as is Rapanui linguist, Viki Haoa Cardinali.

\section{THE 2008 SCHOLARSHIP WINNERS ANNOUNCED!}

THE EASTER ISLAND FOUNDATION's 2008 SCHOLARSHIP winners include Rutiranghi Tuki Paoa, who is in her second year of studying architecture at the Universidad Mayor in Santiago. She writes that, "My plans for the future are to finish my career studies in architecture, to obtain knowledge for returning to the island not 'with empty hands' but to be able to help make changes and bring innovations to my people. I plan to finish my studies and arrive back at the island with a professional title - and to become someone. Thank you very much."

Scholarship winner, Maria Eugenia Huke Funtes, is studying History, Geography and Social Sciences at the Universidad Católica de Valparaíso. Maria is in her 4th and next-to-last year of studies and, if all goes as planned, in two years she will be working as a history teacher on Rapa Nui. In the coming two years, her scholarship will be a significant help as she is studying and living far from home. Maria is very grateful for the EIF award for it will "lighten the load" of studying on the continent.

Our third award winner is Alan Tepano Haoa who is studying industrial design/planning at the Universidad Católica de Valparaiso; Alan is working on his final university project and plans to return to Rapa Nui after graduation where he hopes to work on projects that improve life on the island.

Our Wiegand Scholarship award winner, Juana Luna Atamu, who is studying medicine in Argentina, recently sent us news of her studies. She has finished her coursework in neurology and is now involved in preparing for her final exams. Her clinical studies are continuing and, by mid-year, she will begin her internship. We are very proud of all of our Scholarship Award winners!

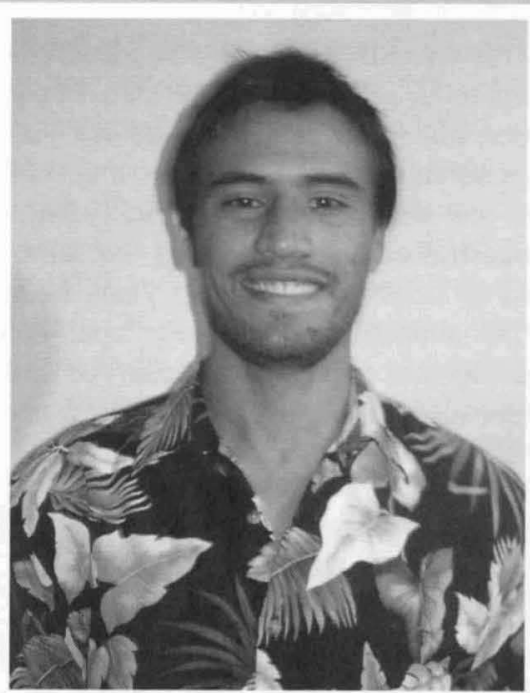

Alan Tepano Haoa, 2008 scholarship recipient.

\section{GREeTINGS From BAYWOOD PARK!}

THE BIG NEWS IS THAT WE MOVED in January to a new office, just a few blocks from our previous location. We are a bit further from the bay, but do have a nice view of it. Our new office is roomier and more visitor-friendly, so if you are ever in Baywood Park, stop and see us!

We have two new books to announce: the first is Prehistoric Rapa Nui, Landscape and Settlement Archaeology at Hanga Ho'onu, by Christopher Stevenson and Sonia Haoa, with contributions by Joan Wozniak, Paul Wallin, and Helene Martinnson-Wallin. The book details the ancient Rapa Nui landscape and describes how it was a highly transformed and managed agricultural terrain that emerged in response to deforestation. It sells for $\$ 30$.

Our second new book is Easter Island 1793 to 1861. Observations by Early Visitors before the Slave Raids, by Rhys Richards. This book contains an exhaustive collection of reports, letters, and accounts from the first ships to visit Easter Island, prior to the slave raids. Many have never before been published which makes this illustrated book very interesting to read. It sells for $\$ 15$.

Thanks to some very kind donors, we have several "new" used and rare books about Easter Island and other Pacific Islands for sale; please check our website for an up-to-date listing. Some are real treasures to be found! Also, we often have slightly damaged copies of our books that we sell at a considerable discount.

Please keep an eye on your Rapa Nui Journal address label for the expiration date of your membership (if you receive a notice in your issue of the Journal about renewing, please fill it out and send it to us as soon as possible). We really appreciate your timely renewal! If you have any questions about your membership, are missing any back issues of Rapa Nui Journal, or if you have any other questions. 